\title{
II. ヒューマンエラーの研究に必要な工学手法
}

\section{野 呂 影 勇 (早稫田大学)}

\section{1.はじめに}

ヒューマンエラーに対してどのような研究のアプロ 一チがなされているかについて，二つ，すなわち動き の素早さと，なぜ間違えるかに较って解説する。もと より, 様々のアプローチが可能であるし, 実際に行わ れている。(財)電力中央研究所のヒューマンファクタ 一研究センターのヒューマンファクタ文献情報に詳し く揭載されている件数も平成 4 年 1 月までで， 1.500 件あり，これらの文献のなかには，ヒニーマンエラー を报っているものも多く，そしてアプローキも多様て ある。二つに絞ったのは，読者の大半が，システムの ヒューマンファクタについて親しみが薄いことを配慮 して，入門的な内容にしたためである。ところで，上 エーマンファクタという用語は，日本語に訳すと人間 工学のことである。エルゴノミクスという用語も使わ れる。人間工学の測定の基本的なコンセプトを表 1 に 示す。

表 1 は，単に概念を示したにすぎない。実際上は， 对象や，目的により異なってくる。表 2 は源子力発電 所の集中監視室のパネルの場合である。

表 2 注，表1と一見無関係のようにも見えるが， そ うではない。表 3 のなかにいくつか出てくる“視線” は，人がどこを見ているか，すなわち，注視点を知る ため人間工学で代用特性としてよく使われるものであ る。湘定された視線は, 視線の移動速度や移動距晟と 角度などの項目について解析されるし，時として視線 と證まりの関係を調べたりする。2.1と2.2節では, まず，表 2 の行動や身体の動きに関連して，動きの素 早さを測る方法，そして2.3節ては，注視点を知るた めの方法を紹介する。メンタルな状態を測る方法につ

II. Engineering Methods for Human Error Research. By Kageyu Noro (Waseda University)

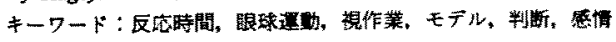

雪学䤅D, 112 巻 4 号, 平成 4 年
表 1 人間工学の測定の基本コンセプト

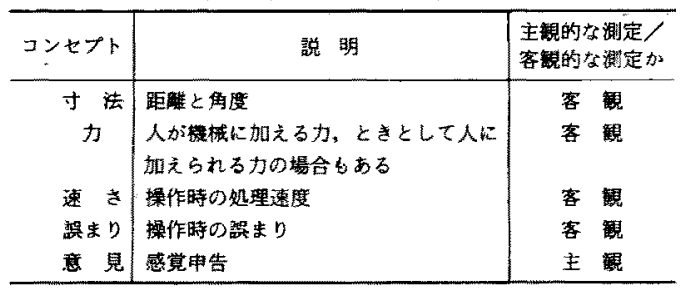

表 2 パネルのデザインの評価の方法

\begin{tabular}{|c|c|}
\hline - 行動の䋊路老㴬る & 多ム/タスク/動作/䂓線/プロトコル゙娄 \\
\hline ・身体各部の動意椡る & ピデオ \\
\hline ・視線の動きを測る & 眼球運陲 \\
\hline ・メンタルな柇整を浰る & 意見邑生理的計濆 \\
\hline
\end{tabular}

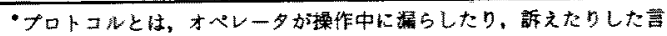

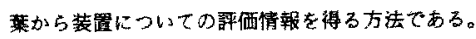

いては心理学政理学の方法が使える。ここでは扱わ ない。

\section{2. 動きの秦早さを測る}

急ぐと間違える。ヒニーマンエラーと動作の早さの 間には密接な関係がある。情報が，一瞬の間に頭の中 でどのように処理されるのか, そして，筋肉に命令を 下すのにどのくらい時間（これを反応時間と呼ぶ）を 要するかは，ヒューマンエラーに密接な関係のある指 標である。まず反応時間の定義について紹介する。

\section{1 反応時間の定義(1)}

ある感覚刺激を受けて，それを意識し，随意的にで きるたり早く反応動作を起すときの，刺激の提示加ら 反応までの時間を反応時間（response time）という。 この反応時間结，

（1）感覚受容と神経繊維を電気信号が伝導するに 要する時間

（2）大脳中枢での情報処理に要する時間

（3）中枢加の指令に上り筋肉を緊張して，体の 必要部分を動かすのに要する時間 
表 3 単純反応時間の実験と選祄反応時間の実験值

\begin{tabular}{|c|c|c|}
\hline \multicolumn{2}{|c|}{ 传純反应 (ms) } & 選択反応 (ms) \\
\hline & 283 & 530 \\
\hline & 255 & 499 \\
\hline & $423^{\circ}$ & 483 \\
\hline 平均侹 & 269 & 504 \\
\hline
\end{tabular}

この表の・の值は，キーから手が滑って失敗したものである。てれ を除いて平均値を計算した。

に関係しており，おおよそ上記 3 要素の合計である。 ところて，中枢神経系は，脳と脊能（脊艏神経䬣と袖 経) から構成される。

まず，目から入った情報（視覚情報という）の処理 がどのように人間の中で行われるのかについて，それ を測る方法として反応速度の実駼を紹介する。

一番簡単な方法としてよく知られているものは，合 図があったら即座にボタンを押すという美験である。 この実験のためには，反法間剆定器なるものが主に 教育用として販売されている。プレイランドのもぐら 吒きもこの一種である。表 3 と表 4 の数値は，単純反 応時間の奏験と選択反応時間の実験から得られたもの である。ここて，笚純反応時間とは，光の刺激が䛱め られたら直ちにキーを㑼すといつた課題である。ほか に選択できる行動はない。選択反応時間とは，赤の信 号て1のキーを押す。青の信号て3のキ一を押すとい つた課題をいう。表 3 に，単純反応封間の実験と選択 反応時間の害験值を示す。この表では，繰返しが 3 回 だけである。もっと多く繰返した方が良さそうである が，少ない綝返しでも，人を変えてもほとんどこの傾 向は変らないという特幑をもつ。

表 3 の单純反応時間の平均值と選択反応時間の平均 值の差は，何加ら起るのかを考えてみよう。まず，筋 肉に命令を下すをての, 経由する人の各部と装置の関
表 4 情報の伝達経路別所要時間(2)

\begin{tabular}{|c|c|c|}
\hline \multirow{2}{*}{ 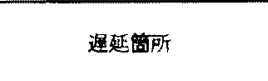 } & \multicolumn{2}{|c|}{ 遲 延 (ms) } \\
\hline & 鞂純反忘 & 邆択反店 \\
\hline 感覓受容器 & $1-38$ & $1 \sim 38$ \\
\hline 求心性神経伝雪 & $2 \sim 100$ & $2 \sim 100$ \\
\hline 中枢娖理 & $70 \sim 100$ & $90 \sim 300$ \\
\hline 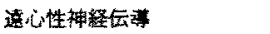 & $10 \sim 20$ & $10 \sim 20$ \\
\hline 笳肉潜時と活性化時間 & $30 \sim 70$ & $30 \sim 70$ \\
\hline 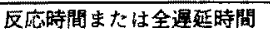 & $113 \sim 328$ & $133 \sim 528$ \\
\hline
\end{tabular}

係を図 1 に示す。

この伝達経路は，人間のどのような生活場面でも成 り立つものである。反応時間については，人間内情報 伝達経路別に数值が計測されている。それを表 4 に示 す。

さて，先ほどの反応時間の夷験で得られた数值（表 3）を表 4 の一番下の欄の数值と比較してみる。単純 反応，選択反応とも、この值の籍囷内にあることがわ かる。ところで，表 4 の両者の数值の差のある簢所 探してみると，中枢処理のところである。従って，両 者の違いは，中枢での判断の難しさの差ということが できる。単純反応時間と選択反応時間の遗いは，中枢 では，その差を $100 \mathrm{~ms}$ ぼの時間として処理してい ることになる。逆にいえは，中枢における仕事の差を 時間の差として捉えていることになる。

さて，ドライバが信号が赤に転じたのを見て，ブレ 一キを踏んだときの様子を取り上げる。車と信号の関 係は，抽象的に描くと，図 2 に示す人間と機械の間の 関係 (マンマシンシステム)で示される。ただし，デ ィスプレイは，交通信呂であってもよいが,この図て は車のメータである。

図 2 は，古くからある有名なものである。人間と機 械のシステム、これをマンマシンシステムと呼ぶが,

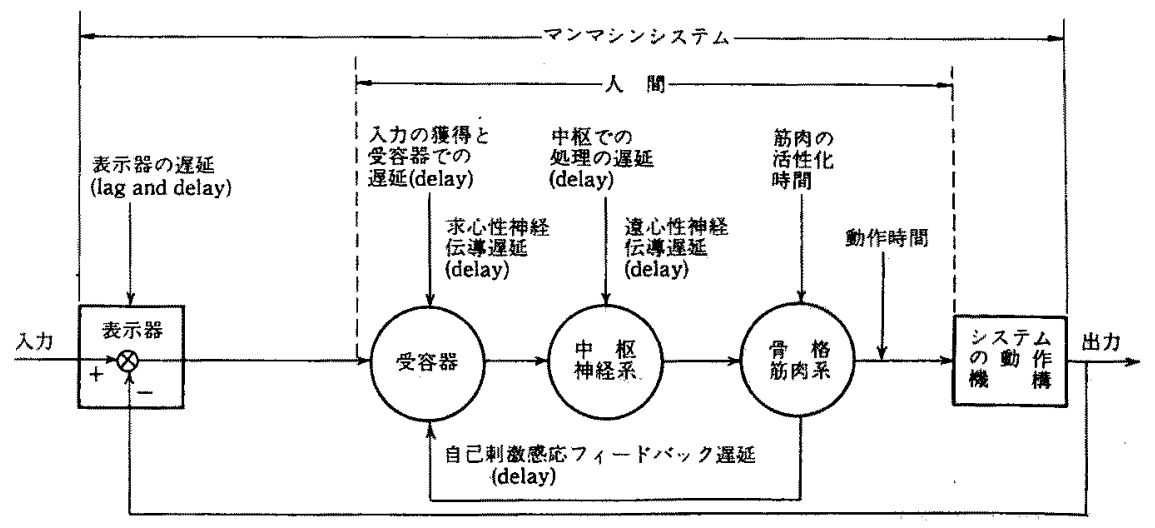

図 1 装置と人間内情報伝達経路の模式図(2) 


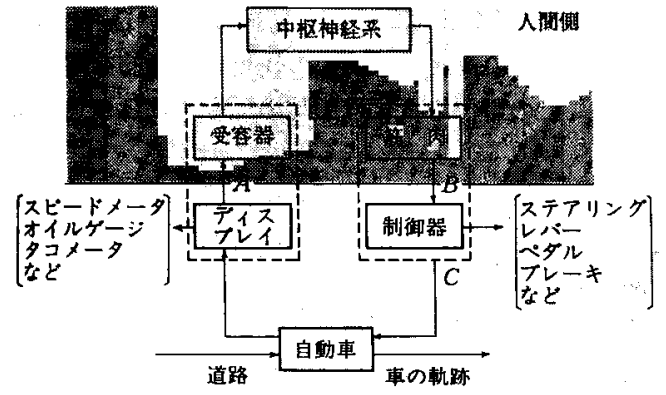

図 2 人間と機械の間のつながり

表 5 自動車の操緃における反応時間の例

\begin{tabular}{|c|c|c|}
\hline & 反応時間 & 応用例 \\
\hline (1) & 足を動かす筋が収摍するまて & $\begin{array}{l}\text { ドライバーが, 初心者か } \\
\text { ベラランか }\end{array}$ \\
\hline (2) & $\left.\begin{array}{c}\text { ブレーキが作㽖開始するまで } \\
\text { まだは } \\
\text { プーキか作勘完了するまて }\end{array}\right\}$ & $\begin{array}{l}\text { ドライバーとブレーキの } \\
\text { 作動の綨合評価 }\end{array}$ \\
\hline (3) & $\begin{array}{l}\text { ドライパーが噇害物を発見したとき } \\
\text { から自動車が停止するまて }\end{array}$ & $\begin{array}{l}\text { ドライバーと自動車から } \\
\text { なるシステムの作動の総 } \\
\text { 合評侕 }\end{array}$ \\
\hline
\end{tabular}

反底時間は変りうる。操維のベテランと初心者の連いて、フレーキペ タルの遊びのありなして连う。

この図は，その基本構造を説明している。また，互い のつながりは, 電気信号であったり, 機械的に力の伝 達であったりする。さて,この図で，反応時間とは， $A$ から中枢を通り $B$ または $C$ までを指す。

\section{2 反応時間の代表的な解秎と応用例}

反応時間の定義に示してある“反応までの時間”に は,いくつか考えられる。先ほどの図 2 の車と信号の 絵で考える。そうすると, 表 5 のように, 三つに分類 される。各々に該当する応用例も示してある。

以上，反応時間について説明した。この反応時間に より, 中枢神経の働きをとらえることが理解できたで あろう。ところで，急ブレーキが上手だったりすると 反射神経がよいなどという場合がある。しかし，これ は誤まりである。定義にあるように，反応時間は， “それを意識し，随意的に反忘”されることが必要条件 である。そくにいう反射神経での“反射”とは, 神経な どの仕組みにより, 刺激に自動的に反応するものであ る。多くの生存に直接影響を及浑す機構にこの反射の 仕組みが備わっている。

\section{3 眼球運動に基づいた人間の情報処理棰造}

2.1 節で,ドライバが信号が赤に転じたのを見て, ブレーキを踏んだときの様子を取り上げた。この状況 では,ドライバが信号を見て，赤に転じたことを認め

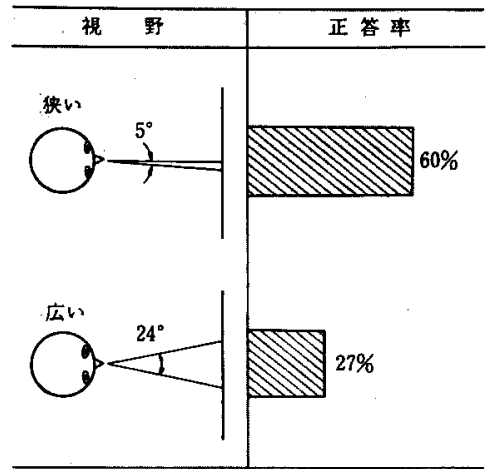

図 3 視野が大きいほど正答率が低下する(3)

ることが前提である。この行為は一瞬の間に行われ る。しかし，ある時間を要することは確かである。 2.1 節で述べた反応時間測定器による実験も同様であ る。しかし, こちらの場合は, 赤や青の表示灯を被験 者の眼前に置くことになるので, 比較的に最小の所要 時間ですむ。これに対して、ドライバが信号を見る場 合は，信号はドライバの眼前に置かれていないからそ れだけ時間を要する。なぜ時間を要するかについては いろいろな要因が考えられるが（例えば対象の認めに くさ), 大きなものの一つに, 視線を移動するのに要 する時間があげられる。例えば, 図 3 は視野の大きさ と詔まりの発生の関係を示している。

人間は，視野が狭い場合は，大きく視線を動かすこ とはないが，24度といった大きな視野では，大きく 視線を動かすことが必要である。視作業においてて人 が採る視野の目安として,ガラス表面の微小きずを検 查するのであれば, 視野は 2 度, ディスプレイ画面全 体を眺める場合， 18 度〜20 度以上となる。ところで， 視線の変化は眼球の運動により生ずる。従って, 眼球 の運動を上手に測定すると，視線の変化が推定でき る。眼球の運動の測定には, 光学的なプロセスによる ものと電気的なものの 2 種類ある。以下にそれらを説 明する。

（1）角膜反射法（光学的方法）の原理 眼球の 角膜は, 曲率半径が約 $8 \mathrm{~mm}$ で, 強膜 (曲率半径約 $13 \mathrm{~mm}$ )に対してやや出っ張っている。角膜表面は鏡 面のように滑らかである。図 4 のようにLED 光を当 てると虚像が生じ，この位置は眼球運動により変る。

図 5 は角膜反射法の装置の一例である。装置はアイ カメラとかアイマークレコーダなどと呼ばれている。 図6はこの装置を用いた測定例である。

角膜反射法の利点は，背景を写しこむことができる ことである。これにより，より説明力がつくともいえ 
るが，視野の周辺部での誤差（測定されたアイポイン トと実際に注視しているポイントとの間の誤差) は多 少出る。欠点は, どうしても装置そのものが重たいこ と，装着するときに頭部にかなりの締め付けを行う製 品などもあって, 長いこと続けていられないという場 合もあることである。

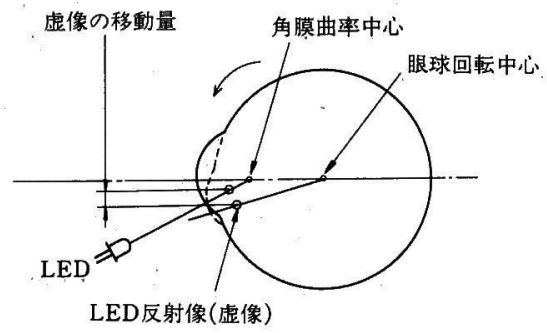

図 4 角膜反射法の画理

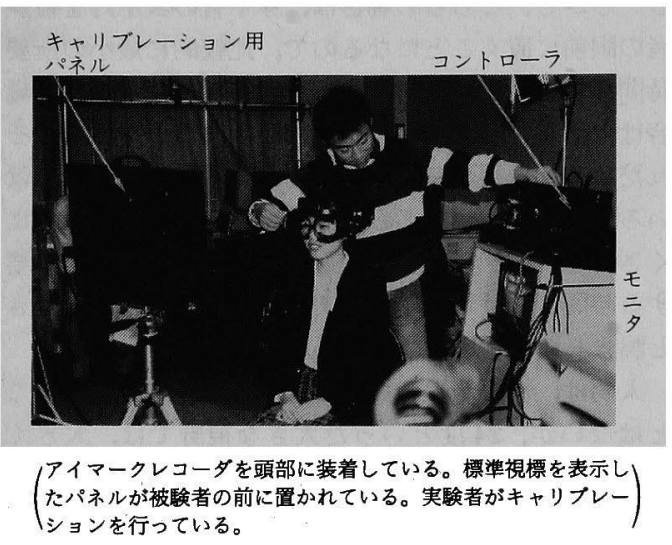

図 5 角膜反射法
（2）眼球電位図法（電気的方法）(Electrooculogram) の原理 網膜の表裏には静的な電位差 がある。この電位の変化は眼球の回転角にほぼ比例す る。

次に測定例を紹介する。図 8 は, ディスプレイ上に 格子状に提示された視標を矢印の方向に見ていく仕事 の図解である。

この場合の眼球電位図法によるグラフは図 9 のよう になる。（a）は，間違えずに視標を見ており，(b) は, 途中乱れが生じている。視標の認め損ないが生じ た可能性大である。ただし，このような規則性の乱れ はまばたきでも生ずることがある。

眼球電位図法の場合には光学的な方法と違って, 人 がみているその風景を映像として撮るということは不 可能である。けれども, グラフとして時間の推移とと もに眼球の回転角度がわかるということはまた重宝な ことも多いのである。この方法の欠点としては, 眼の 上下左右に電極を貼り付けること，あるいはそこから とられた微弱な電流を増幅するためのアンプあるいは

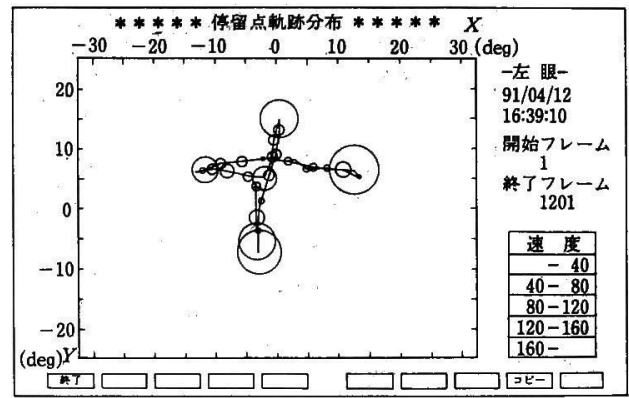

(円は注視点, 円の大きさの遭いは停留時間の違い)

図 6 測定結果の画面表示例(4)
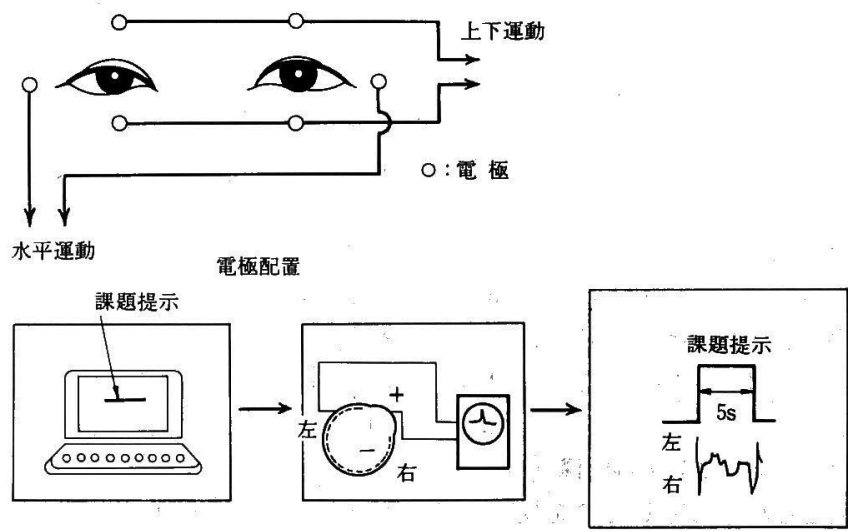

上の図は電極のはりつけ位置, 下図は測定のプロセス図解

図 7 眼球電位図法の原理 


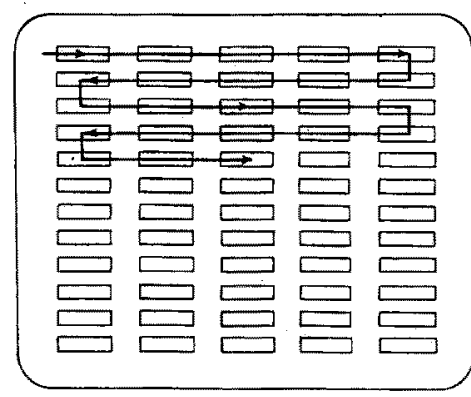

(矢印は視線の移娌)

図 8 画面に表示ざれた奏鈳用視標

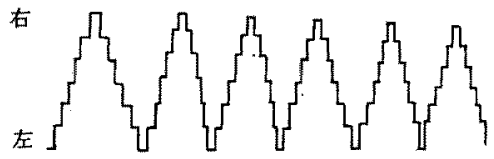

（a）規則正しい既球の電位图

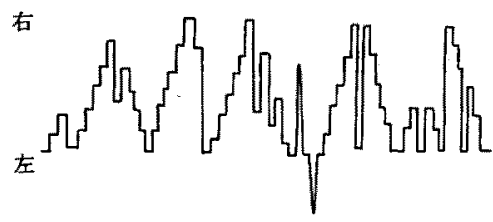

（b）規則性が辞れた眼球笔位图

図 9 眼球電位図法によるグラフ

プロッタなどが必要だということで，かなり生理的な 方法といってよいだろう。

\section{3. なぜ間違えるかを説明するモデル}

急いだために階段を踏みはずす事故は多いものの一 つである。この事故を説明してみよう。まず，人間は 自分の行動を大きく切り替えることができる。例え ば，「急げ」とか「確実に」といつた切り替えである。 「急げ」であれば，速く動作することに比重を置く。 この結果，いつも行っている動作を省いたり，注意や 目配りを省いたりする。これらは，なぜ間䢖えるかを 説明するモデルのひとつといえる。次に，上ューマン エラーに関係するモデルをいくつか紹介する。

\section{1 判断のモテル}

間違った判断もヒューマンエラーの一つである。モ デルを楆築しようとするとき，例外まで入れると叹集 がつかないことから，簡索化する。これは，モデルを 作るときの常道である。しかし，明らかにモデルのも つ本筫的な弱点である。特に，ヒューマンエラーを扱 うとなると弱点である。なぜかというと，事故とかエ
ラーは例外的な事象だからである。さて，判断を説明 するモデルとはどのようなものだろうか。判断は多段 階のステップを経たものとして行われると考え, 䘽雑 な判断も二者択一のステップの樻み重ねと考える。判 断のモデルとしては，ほ加に，人間の内部構成として の機能を明確に記述するという方法もある。例えば， 有限状態系（オートマトン）を想定する。これは，次 のような考えである。人間は，判断を行う場合，機械 と違い，入力と出力の関係が一様ではない。その人間 固有の内部状態に依存して, 同一入力でも異なる出力 を出す。この現象を次のように記述し，これを有限状 態系という。「ある時点の入力と人間の内部状態によ つて人間の出力が定まる」, そして「その時点の入力 とその時点の人間の内部状態によって，次の時点の人 間の内部状態が定まる」。

なお，人間の内部状態とは，例えば，あせっている といった情動的であったり，肉体が疲労しているとい った生理的な状態を含む。このようなモデルの例を図 10 に示す。このモデにおいては，以下6つの要素 を用いている。

(1) 入力 1 : 刺激集合 $F_{i}=\left\{f_{1}, f_{2}, \cdots, f_{p}\right\}$ 入力 2 : 判断基準

(2) 出 力: accept $D_{20}$ および reject $D_{21}$

(3) 状態パラメータ $1:$ : 記憶関数

(4) 112 : 不確実籍囲 (IU)

(5) 113 : ベイズ判定機構

(6) 34 4:主観的等価

このモデルは，定常的な外觀检查を行う人間を想定 して扔り，生理的ないしは心理的な人間の内部状態ま

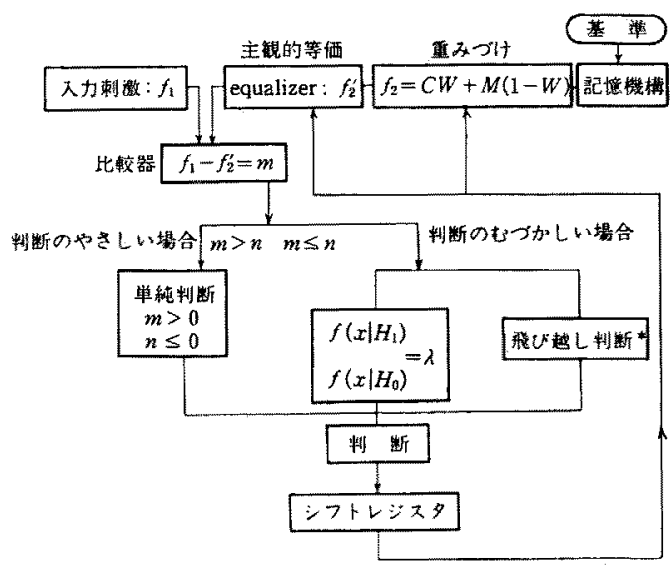

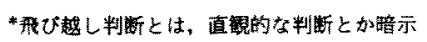
といった別の次元のことでる。

図 10 有限状態系の例 
では扱っていない。換言すれば, シミュレーションを 行う場合, 生理的ないしは心理的な人間の内部状態ま で含めるととても複雑になりすぎるので，そこを避け ている。しかし，既に述べたように，ヒューマンエラ ーとしては問題である。

\section{2 信号検出理論}

この理論は, 人間の信号を検出するときの作業成績 についてのモデルである。このモデルでは, 人間は 2 通りのエラーを犯すと仮定している。すなわち,

第 1 種のエラー： 合格にするべき製品を不合格と する。あわて者の誤まりという。

第 2 種のエラー： 不良品を合格とする。ほんやり 者の誤まりという。

監視室などでのプロセスの不具合は, この不良品に 相当し, これを信号と呼ぶ。詳しくは, 文献 (6)を参 照されたい。

\section{3 注意システムのモデル}

見たり，聞いたり，覚えたり，考えたりする働きを 総称して認知機能と呼ぶ。この機能を情報処理の用語 で記述していこうとする心理学の領域が認知心理学で ある。1970 年ごろからいろいろなモデル(例えば, 短期長期記憶モデル）が提案されている。特に, 1980 年代に, パソコンの普及に伴いソフトウェアの設計原 理の理論的な支えになり，一種の流行となった。エラ 一のうち, 見誤まり, 聞き間違いなど, 人間の認知系 に起因するものを認知エラーと呼ぶ。この認知エラー を記述するモデルとして，例えば，Normanの注意 システムのモデル(7)がある。このモデルの弱点もかな りある。それは, あくまで記述のモデルであることで ある。たしかに, ある状況を説得力をもって記述する ことは大切であろう。しかし, 工学の立場としては, そのモデルから設計のパラメータが得られにくいとい うもどかしさがある。シンボルやアイコン, コマンド 入力方式, 入力デバイスおよび仮想スイッチ類の動作 の規定あるいは, ユーザとの対話手段や画面デザイン など, 認知心理学と人間工学の共通の対象である。人 間工学の場合, 説明力に欠けるきらいがあるが, 反 面, 操作までも含めて使いやすさや認めやすさを論ず るのが人間工学であろう。設計にあたっては, 認知心 理学と人間工学の使い分けが実際的であろう。

\section{4. まとめ}

1980 年代に至り, システムの自動化あるいは無人 化には, ある限界があることが認識できたと考えられ る。自動化できないとなれば, システムに人間をどの ように組み込むかが大切である。もう一つは, システ
ムエラーの発生確率は確実にそして限りなくゼロに近 づきつつある。同時に, 人間を組み込む以上, ゼロに は到達しないことも明らかである。ヒューマンエラー の研究では, 黙っていれば着実に手詰まり状態に追い 込まれる。新たな工学的な方法が望まれる。例えは中, ファジー推論の利用もその一つであろう。ファジーが 良い例であるが, 新たな工学的な方法というのは, 従 来工学が避けていた領域に進出することかも知れな い。認知の情動依存性はよく知られていることである が, 人間の感情とか情動を計測したり伝達することな どもこれからの方法と考えられる ${ }^{(8)}$ 。これとは逆で あるが,もっと人間の日常的な行動を組み込むことも 必要であろう。例えば図書館の情報検索で, 画面を使 って検索することが効率はよさそうである。しかし， 開架式の閲覧も捨てがい。あっちこっち歩いている間 に, 目的とは異なる本を発見したりする。この 10 年 ばかり認知心理学などの流行で, 頭脳にばかり関心か 向いているきらいがありそうである。人間について, 認知, 行動, 身体などを含めた総合的な工学的な方法 が更に必要である。

(平成 4 年 3 月 25 日受付)

\section{文献}

（1）野呂:「人間工学における反応時間の測定と結果の解析】 人間工学, 21,2 (昭60)

(2) Michael J. Wargo: "Human Operator Response Speed, Frequency, and Flexibility", A Review and Analysis, Human Factors, 9, 3(1967)

（3）野呂: 職場の人間工学, p. 131 (昭 61) 日本規格協会

(4) 野呂, 他: エルココノシクスデザイン, p. 41 (平 3) 日科技連

（5）野呂: 「検查計測の研究法」人間工学, 15, 6, 289 (昭 54)

（6）野呂：官能検查ガイドブック, p. 246〜249（昭 52） 日本规格 協会

（7） D. Norman., 富田達彦, 他訳: 記境の科学, p. 112 (昭 51) 紀伊 国屋書店

（8）野呂: 生活のための工学, p. 269 (平 4) 放送大学教育振興会

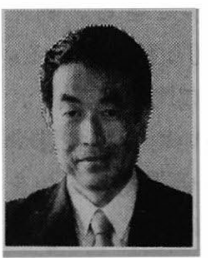

\section{野 呂 影 勇}

昭和 34 年早稲田大学理工学部電気工 学科卒業。会社勤務の後, 46 年より慶 応義塾大学理工学部講師, 54 年産業医科 大学医学部人間工学教室教授に就任。60 年より同大大学院医学研究科生理情報学担当教授を兼任。 61 年早稲田大学理工学部教授, 62 年より人間科学部教授, 平成 3 年より放送大学客員教授を兼任。工学博士。最近の 研究はワークステーションの設計理論, ビデオを用いたコ ミュニケーションデバイスの開発など。電子協ニューオフ イスシステム委員会委員長, グッドデザイン賞審査委員。

編著書：図説エルゴノミクス (1990), Participatory Ergonomics (1991), 生活のための工学 (1992)。 